\title{
Demonstration of reticulin fibres in the epididymis of adult male wistar rats (Rattus norvegicus)
}

\author{
UKWENYA, V. O. ${ }^{1 *}$, ASHAOLU, O. J. ${ }^{2}$, ALESE, O. ${ }^{1}$, OLUYEMI, K. A. ${ }^{3}$, \\ OJO, G. ${ }^{2}$ and ASHAMU, E. ${ }^{4}$ \\ ${ }^{1}$ Department of Anatomy, College of Medicine, Ekiti State University, 23401 Ado-Ekiti, Nigéria \\ ${ }^{2}$ Bowen University, Iwo, Nigéria \\ ${ }^{3}$ Department of Biology/Biotechnology, William Paterson University, Wayne, NJ, United States of America \\ ${ }^{4}$ Department of Anatomy, College of Medicine, Ladoke Akintola University, 23401 Ogbomoso, Nigéria \\ *E-mail: victorwyn@yahoo.com
}

\begin{abstract}
Introduction: The epididymis is a tube of smooth muscle lined by a pseudostratified epithelium; the duct is lined by smooth muscle and the stroma is made up of connective tissue. Reticulin fibres are fine fibres that contain primarily collagen type III that are secreted by reticular cells and are traditionally thought to be present only in soft blood-forming tissues such as kidney, liver, bone marrow and organs of the lymphatic system such as thymus. Methods: This work demonstrates for the first time the presence of reticulin fibres in the epididymis of adult male Wistar rats using silver impregnation method. Results: The results show reticulin fibres around the peritubular ductal walls and in the connective tissue stroma. Conclusion: The presence of reticulin fibres within the epididymal connective tissue may have effect on contractility, assisting the movement of sperms from the caput portion of the duct to the caudal part.
\end{abstract}

Keywords: connective tissue, epididymis, reticulin fibres, tunica vaginalis, Wistar rats.

\section{Introduction}

The epididymis is an organ made up of highly coiled tube that courses along the posterolateral surface of the testes and has two distinct components: i) the efferent ductules, which form an elongated coiled mass that sits on the posterior superior pole of the testis and forms the head of the epididymis (DRAKE, VOGL and MITCHEL, 2005) ; ii) the true epididymis, which is a single, long coiled duct into which the efferent ductules all drain, and which continues inferiorly along the posterolateral margin of the testis as the body of epididymis and enlarges as the tail of epididymis at the inferior pole of the testis (DRAKE, VOGL and MITCHEL, 2005).

Histologically, the duct of the epididymis is dominated by a tall, pseudostratified columnar epithelium (MARIEB, MALLAT and WILHEM, 2005). The luminal surface bears tufts of long microvilli called stereocilia, which are not cilia and do not move (MARIEB, MALLAT and WILHEM, 2005). Instead they provide the tall epithelial cells with a vast surface area for reabsorbing testicular fluid and for transferring nutrients and secretions to the many sperms that are stored in the lumen of the epididymis (MARIEB, MALLAT and WILHEM, 2005). The principal cells are tall columnar epithelium and are lined with stereocilia, the long branching microvilli (EROSCHENKO, 2008). The basal cells are small and spherical and situated near the base of the epithelium (EROSCHENKO, 2008).

From the proximal to the distal end of the epididymis, the muscular layer increases from a single circular layer to three layers organised in the same manner as in the ductus deferens (FAWCETT, 1994). Proximally, the smooth muscle exhibits slow rhythmic contractility which gently moves spermatozoa towards the ductus deferens (FAWCETT, 1994). Distally, the smooth muscle is richly innervated by the sympathetic nervous system which produces intense contractions of the lower part of the epididymis during ejaculation (FAWCETT, 1994). Adjacent to the smooth muscle layer are cells and fibres of the connective tissue (EROSCHENKO, 2008).

Reticulin fibres are fine fibres that contain primarily collagen type III that are secreted by reticular cells (STRUM, GARTNER and HIATT, 2007) and are traditionally thought to be present only in soft blood-forming or blood-processing tissues such as kidney, liver, bone marrow and organs of the lymphatic system such as thymus (SALADIN, 2010). However, Bilaspuri (1992) reported the presence of reticular fibres in the peritubular connective tissue of the epididymis of prepubertal goats. Fakoya (2002) also demonstrated the presence of reticulin fibres in the tunica albuginea and peritubular tissue of seminiferous tubules of adult rat testes after staining with the metallic silver impregnation method.

There is a dearth of literature relating the identification of reticulin fibres within the epididymis of wistar rats. This paper describes the identification and characterization of reticulin fibres in the epididymis of adult male Wistar rats.

\section{Materials and Methods}

Eight adult male Wistar rats (Rattus norvegicus) weighing between 160 and $180 \mathrm{~g}$ were used for this study. The rats were purchased from the University of Ibadan, Ibadan, Nigeria and housed in the Animal House of the department of Anatomy, Bowen University, Iwo, Nigeria under standard laboratory 
conditions. The rats were fed rat chow (Ladokun Feeds, Ibadan) and water ad libitum.

The procedures involving animal use in this study were in compliance with the guiding principles for research involving animals as stipulated by the declaration of Helsinki and the guiding principles in the care and use of animals (WORLD MEDICAL ASSOCIATION and AMERICAN PHYSIOLOGY SOCIETY, 2002) and was approved by the Departmental Committee on the use and care of animals.

The rats were sacrificed by anaesthesia using chloroform. The animals were opened up by abdominopelvic incision and the testis harvested. After sacrifice, the testes were dissected out, trimmed of all fat and then excised.

The epididymis were excised from the testis, blotted dry and fixed in Bouin's fluid. The fixed tissues were transferred to graded series of ethanol and then cleared in xylene. The tissues were then infiltrated in molten paraffin wax in the oven at $58^{\circ} \mathrm{C}$. Serial sections of $5 \mu \mathrm{m}$ thick were obtained from a solid block of tissue on rotary microtome (Leica Rm 2135, England). The sections were fixed on clean slides, stained with Haematoxylin and Eosin stains and silver impregnation according to the method of Gordon and Sweet (1936).

\subsection{Silver impregnation of sections}

Sections were immersed in water and then oxidised in acidified potassium permanganate for 5 minutes. The sections were washed in water and then bleached in $1 \%$ oxalic acid for 5 minutes. This was followed by rinsing in distilled water. Sections were then mordanted in $2.5 \%$ iron alum for 15 minutes, and thereafter washed in three changes of distilled water, after which they were then immersed in silver solution until they became transparent. Sections were then reduced in $10 \%$ formalin for 1 minute. Toning followed in $0.2 \%$ gold chloride for 15 minutes until sections turned into purple. Sections were then washed briefly in distilled water and were thereafter immersed in sodium thiosulphate for 5 minutes. They were then washed in water for 1 minute. Sections were then dehydrated, cleared and mounted.
Photomicrographs were taken with the aid of a high definition digital camera, Leica ICC50 (Leica Microsystems, England) was mounted on a microscope Leica DM 750 (Leica Microsystems, England).

\section{Results}

$\mathrm{H}$ and $\mathrm{E}$ sections of the epididymis featured large tubules lined with ciliated pseudostratified epithelium. The columnar cells presented with basal and principal cells. The tubules were distended with luminal sperm aggregate and were surrounded by a distinct layer of smooth muscle (Figure 1A, B).

Silver impregnation revealed the presence of distinct rims of black-stained reticulin fibres around the peritubular walls of the epididymis (Figure 2A). The connective tissue stroma revealed concentric rings of reticulin fibres (Figure 2B). Present in the tunica vaginalis were a dense meshwork of reticulin fibres.

\section{Discussion}

Traditionally, the peritubular walls of the epididymis are described to consist of smooth muscle fibres and the stroma connective tissue (Figure 1A and B). However, this study demonstrated the presence of reticulin fibres within the epididymis. The reticulin fibres formed a wavy meshwork that extended from the tunica vaginalis and ramified within the connective tissue (Figure 2A and B). They were also present within the peritubular walls of the epididymis in addition to the smooth muscle layer found there.

The cytology and organization of the musculature of the epididymis is well correlated with the motility of its duct system. The presence of reticulin fibres within the connective tissue of all parts of the epididymis would have effect on contractility, assisting the movement of sperms from the caput portion of the duct to the caudal part. Its impact on transit time through the duct would also be significant, aiding sperm maturation and the absorption of fluid. Reports relating the presence of epididymal reticulin fibres in human subjects are associated with pathological conditions. Mavrov, Takov and Tsvetkov
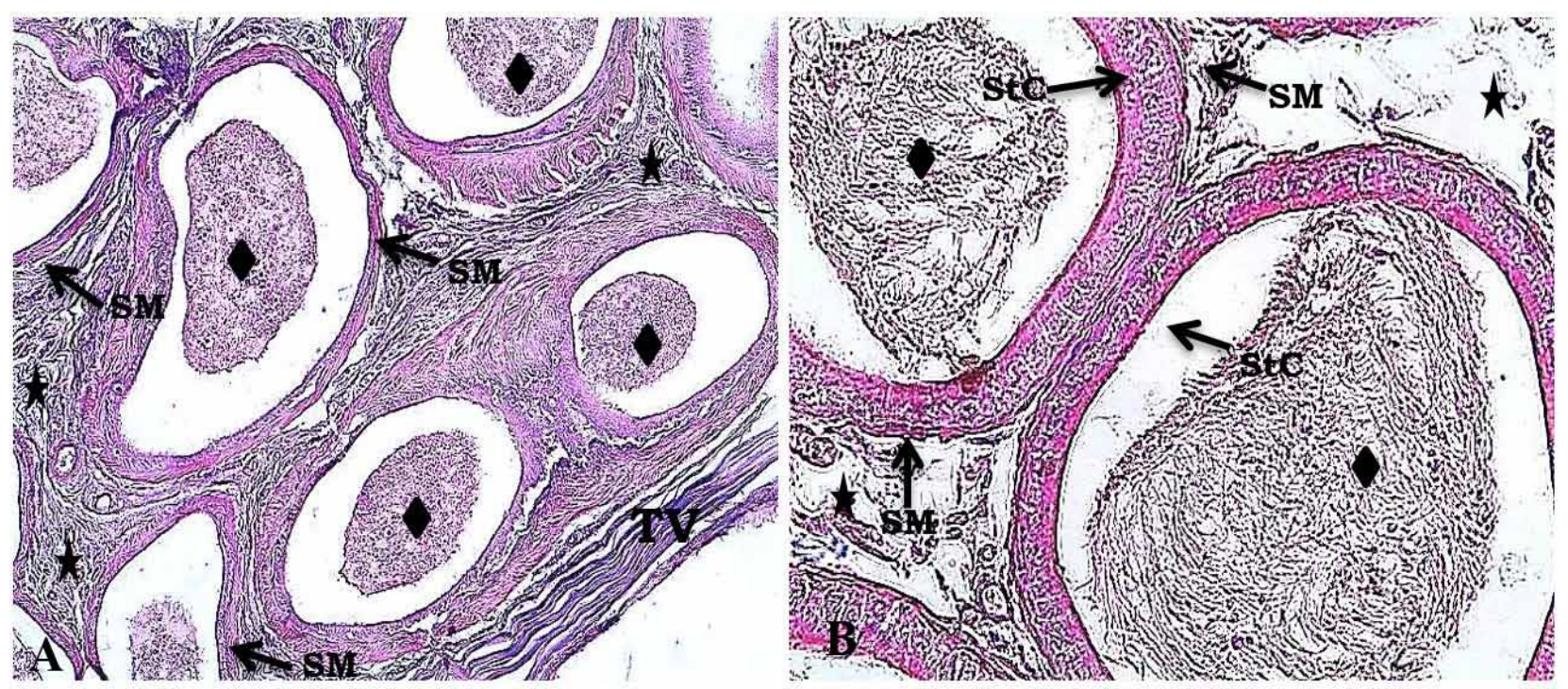

Figure 1. Sections of epididymis of adult male wistar rats. Stain: H\&E; Mag:A x 100; B x 400. Rhomboids indicate luminal sperms; stars indicate connective tissue; $\mathrm{StC}=$ stereocilia; $\mathrm{SM}=$ smooth muscle; $\mathrm{TV}=$ Tunica vaginalis. 

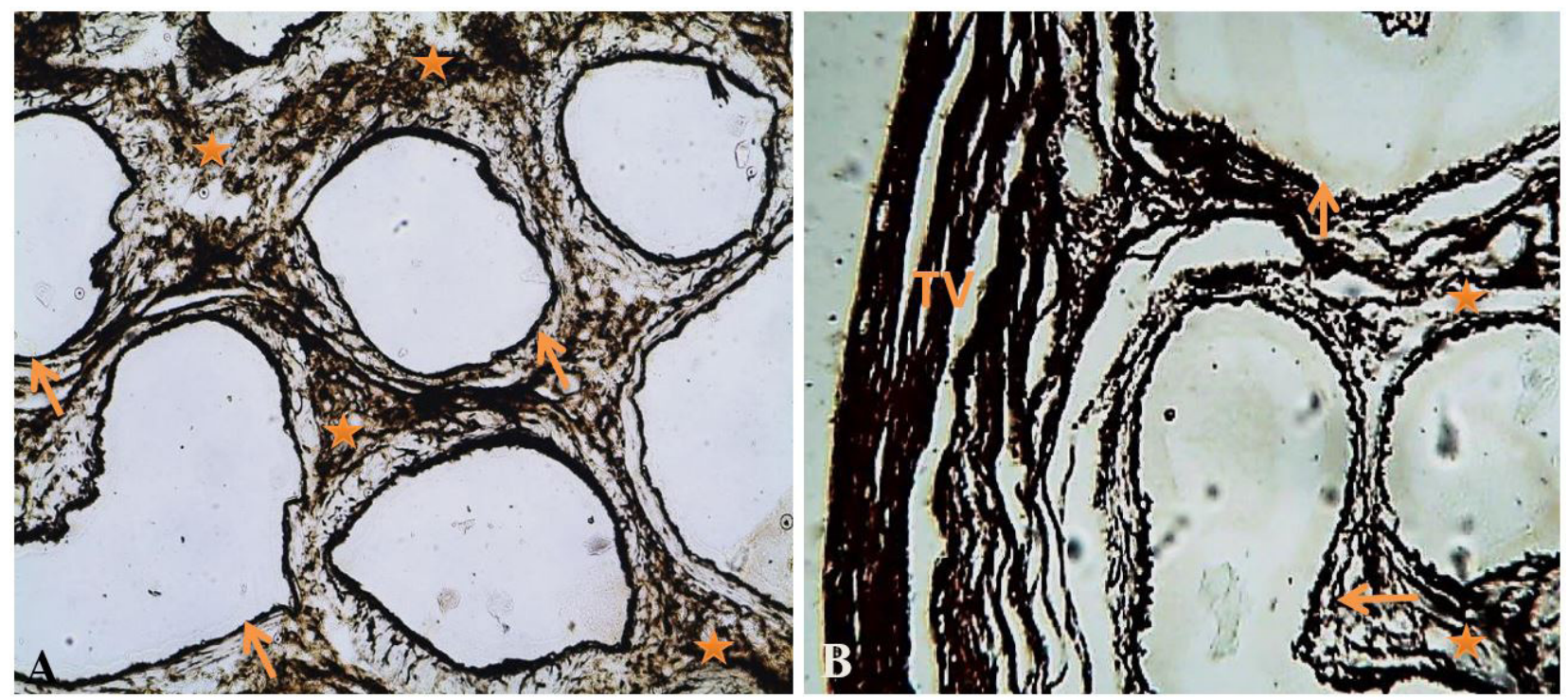

Figure 2. Sections of epididymis of adult male wistar rats. Stain: Gordon and Sweet's. Mag x: 100. (A) Arrows indicate retticulin fibres around the peritubular wall of the ducts; stars indicate reticulin fibres within the connective tissue. (B) The tunica vaginalis (TV) shows a dense wavy arrangement of reticulin fibres.

(1990) in a clinico-morphological study of epididymal cysts reported fibrous tissue and different proportion of smoothmuscle, elastic and reticular fibers. Also multiple noncaseating epithelioid granulomas with concentric arrangement of reticular fibers was reported by Hassan, El-Mogy, Zalata et al. (2009) in a case of bilateral epididymal sarcoidosis. Because of the supporting role of connective tissues in maintaining structural integrity, the state of the epididymal reticulin fibres in pathological states in rats would be of interest.

In this study, reticulin fibres were abundantly localised in the connective tissue stroma and around the peritublar walls. Like in the testes (FAKOYA, 2002), the reticulin fibres within the the tunica vaginalis were orientated in discreet lamella parallel to the main axis of the epididymis. The presence and similarity of arrangement of reticulin fibres in the testis and epididymis of adult male Wistar rats could be an indication of the pivotal role the fibres play in male reproductive anatomy and physiology.

\section{Conclusion}

Since reticulin fibres contain mainly collagen type III, it could be argued that the strength and pliability that they confer facilitates not only a centre-to-periphery progression of spermatozoa (FAKOYA, 2002) but also the movement of sperms from the caput of the epididymis to the caudal part and thereby aiding intromission.

\section{References}

BILASPURI, GS. Histomorphology of the epididymis in prepubertal goats. Small Ruminant Research, 1993, vol. 10, n. 3, p. 227-235. http://dx.doi.org/10.1016/0921-4488(93)90127-4.

DRAKE, RL., VOGL, W. and MITCHEL, WM. Gray's anatomy for students. London: Churchhill Livingstone, 2005. 406 p.
EROSCHENKO, VP. DiFiore's atlas of histology. 11 th ed. Philadelphia: Lippincott Williams and Wilkins, 2008. 411 p.

FAKOYA, FA. Reticulin fibres in the tunica albuginea and peritubular tissue of seminiferous tubules of adult male wistar rats. Acta Histochemica, 2004, vol. 104, n. 3, p. 279-283.

FAWCETT, DW. A textbook of histology. 12th ed. London: Chapman and Hall, 1994. 803 p.

GORDON, H. and SWEETS, HH. A simple method for the silver impregnation of reticulum. American Journal of Pathology, 1936, vol. 12, n. 4, p. 545-551. PMid:19970284. http://dx.doi.org/10.1002/ path.1700430311.

HASSAN, A., EL-MOGY, S., ZALATA, K. and MOSTAFA, T. Bilateral epididymal sarcoidosis. Fertility and Sterility, 2009, vol. 91, n. 5, p. 1957. http://dx.doi.org/10.1016/j.fertnstert.2008.12.091. PMid:19249026.

MARIEB, EN., MALLAT, J. and WILHEM, PB. Human anatomy. 5th ed. San Francisco: Pearson Benjamin Cummings, 2005. p. 718.

MAVROV, KH., TAKOV, R. and TSVETKOV, D. Clinico-morphological studies of epididymal cysts. Khirurgiia, 1990, vol. 43, n. 5, p. 56-61. PMID: 1715419

SALADIN, KS. Anatomy and physiology, the unity of form and function. 5th ed. New York: McGraw-Hill Companies, 2010. 162 p.

STRUM, JM., GARTNER, LP. and HIATT, JL. Cell biology and histology. Philadelphia: Lippincott Williams \& Wilkins, 2007. 83 p.

WORLD MEDICAL ASSOCIATION and AMERICAN PHYSIOLOGY SOCIETY. Guiding principles for research involving animals and human beings. American Journal of Physiology. Regulatory, Integrative and Comparative Physiology, 2002, vol. 283, n. 2, p. R281-R283. PMid:12121837. http://dx.doi.org/10.1152/ajpregu.00279.2002.

Received April 28, 2015 Accepted October 20, 2016 